\title{
Conserved karyotypes in the Hyla pulchella species group (Anura, Hylidae)
}

\author{
FERNANDO ANANIAS ${ }^{1}$, PAULO C. A. GARCIA ${ }^{2}$ and SHIRLEI M. RECCO-PIMENTEL ${ }^{3}$ \\ ${ }^{1}$ Programa de Pós-Graduação em Biologia Celular e Estrutural, Instituto de Biologia, Universidade Estadual de \\ Campinas (UNICAMP), Campinas, SP, Brasil and Universidade São Francisco, Bragança Paulista, SP, Brasil \\ ${ }^{2}$ Programa de Pós-Graduação em Zoologia,Universidade Estadual Paulista (UNESP), Rio Claro, SP, Brasil \\ ${ }^{3}$ Departameno de Biologia Celular, Instituto de Biologia, Universidade Estadual de Campinas (UNICAMP), \\ Campinas, SP, Brasil
}

\begin{abstract}
Ananias, F., Garcia, P. C. A. and Recco-Pimentel, S. 2004. Conserved karyotypes in the Hyla pulchella species group (Anura, Hylidae). - Hereditas 140: 42-48. Lund, Sweden. ISSN 0018-0661. Received August 19, 2003. Accepted November 18, 2003

Cytogenetic analyses were done on specimens of Hyla marginata and on three populations of $H$. semiguttata differing in morphology and in the physical parameters of their advertisement call, as well as in individuals of Hyla sp. (aff. semiguttata). All specimens had $2 \mathrm{n}=24$ chromosomes with a morphology very similar to that of other 24-chromosome Hyla species. Hyla semiguttata and $H$. marginata showed the same C-banding pattern but were distinguished by the location of the NOR on pair 1 in $H$. semiguttata (in the three populations) and Hyla sp. (aff. semiguttata), and on pair 10 in H. marginata. The $H$. semiguttata populations did not differ cytogenetically, despite variations in their morphology and advertisement calls. Similarly, H. semiguttata and H. p. joaquini studied previously had identical C-banding patterns and NOR locations, suggesting that they are very closely related.
\end{abstract}

Shirlei M. Recco-Pimentel, Departameno de Biologia Celular, Instituto de Biologia, Universidade Estadual de Campinas (UNICAMP), 13084-971 Campinas, SP, Brasil. E-mail: shirlei@unicamp.br

According to LuTz (1973), the Hyla pulchella group, previously known as Hyla raddiana, occurs in Brazil, Uruguay and Argentina. The group was defined by DuELlman et al. (1997) as consisting of the following species, excluding the related species of the Hyla circumdata group: Hyla pulchella pulchella Duméril and Bibron, 1841; H. pulchella joaquini Lutz, 1968; $H$. pulchella cordobae Barrio, 1965; H. pulchella riojana Koslowski, 1895; H. andina Müller, 1924; H. semiguttata Lutz, 1925; H. marginata Boulenger, 1887; $H$. prasina Burmeister, 1856; H. cymbalum Bokermann, 1963; H. albonigra Nieden, 1923; H. balzani Boulenger, 1898; H. marianitae Carrizo, 1992; H. melanopleura Boulenger, 1912 and H. palaestes Duellman, De La Riva and Wild, 1997. Farvovich (1996) and Caramaschi and Cruz (2000) included $H$. caingua Carrizo, 1990 and H. ericae Caramaschi and Cruz, 2000 in the pulchella group. In addition, GARCIA et al. (unpubl.) raised the subspecies $H . p$. joaquini to the full species category because of its larger size, robust arms and distinct acoustic parameters compared to Hyla p. pulchella.

The characterization of the pulchella group is difficult. The species considered to be part of this group have the following characters: (1) a moderately robust body and a proportionally long, wide head, (2) flanks and inner thigh areas with a pale coloration and black bars or reticulations, or dark thighs and flanks with pale spots, (3) males with hypertrophied forearms but a well developed prepolex terminating in a spine, (4) an advertising call consisting of a series of "bell type" notes, (5) reproduction in flowing water, and (6) a brown, green or gray dorsal color, generally with dark spots, reticulations or transversal bars (Duellman et al. 1997).

In an attempt to clarify the relationships within the large pulchella group, GARCIA et al. (2001) suggested that the species $H$. marginata, $H$. semiguttata, $H$. $p$. joaquini and $H$. ericae form a subgroup within the Hyla pulchella group based on certain common characteristics, including the absence of stains or dark bars on the flanks and on the inner surface of the thighs, long, multi-pulsed acoustic notes, and reproduction in creeks.

Hyla marginata is found in the southern Brazilian states of Rio Grande do Sul and Santa Catarina (GARCIA et al. 2001) and H. semiguttata Lutz in the states of Rio Grande do Sul, Santa Catarina and Paraná in Brazil, as well as in northwestern Argentina (Lutz 1925; Cei and Roig 1961; Lutz 1973; Braun and Braun 1980). The relationship between $H$. marginata Boulenger and $H$. semiguttata Lutz within the pulchella group is unclear. LuTz (1973) suggested that $H$. marginata was similar to $H$. $p$. joaquini in some characters. LANGONE (1993) considered H. semiguttata and $H$. p. joaquini synonymous with $H$. margin- 
ata. Morphological differences have been observed in specimens of $H$. semiguttata from southern of Brazil and northwestern Argentina (P. C. A. Garcia, pers. obs.).

GARCIA and HADDAD (1999) reported the existence of different populations which they referred to as belonging to the marginatalsemiguttata complex. Analysis of the advertising calls of populations of $H$. semiguttata and $H$. marginata showed that $H$. marginata had call parameters that differed from those of $H$. semiguttata. All populations of $H$. semiguttata studied so far (Misiones, Argentina; Cambará do Sul and São Francisco de Paula, RS, and Piraquara, PR, Brazil) show significant differences in their call patterns, which suggests the existence of more than one species under the same name.

Considering the difficulty in defining $H$. marginata and $H$. semiguttata, as well as the uncertain relationships among species of the pulchella group and between this and other groups (polytaenia and circumdata), the aim of this study was to compare cytogenetically three populations of $H$. semiguttata and one population of $H$. marginata in order to clarify some of these issues.

\section{MATERIAL AND METHODS}

Specimens of H. marginata, H. semiguttata (populations of Cambará do Sul, São Francisco de Paula and Piraquara, Brazil) and Hyla sp. (aff. semiguttata) from Argentina were collected and deposited in the collection of the Dept of Zoology of the State University of São Paulo (UNESP), Rio Claro, SP, Brazil (Table 1).

Chromosomal preparations were obtained after intraperitonial injection of aqueous solution of $2 \%$ colchicine $\left(0.02 \mathrm{ml} \mathrm{g}^{-1}\right.$ of body weight). After at least $4 \mathrm{~h}$ the intestines and testes were removed to prepare the cell suspensions (SCHMid 1978; SCHMID et al. 1979). Metaphase preparations stained with $10 \%$ Giemsa solution were photographed with an Olympus BX60 microscope. The chromosomes were classified according to their centromere position based on the nomenclature and centromeric index proposed by Green and Session (1991).

The constitutive heterochromatin pattern and NOR localization were assessed using the C-banding (Sumner 1972) and Ag-NOR (Howell and Black 1980) techniques, respectively.

\section{RESULTS}

\section{Karyotypes}

All populations of $H$. marginata, $H$. semiguttata, and Hyla sp (aff. semiguttata) had $2 \mathrm{n}=24$ chromosomes. Pairs 1, 2, 8, 11 and 12 were metacentric, pairs 3, 5, 7, 9 and 10 were sub-metacentric, and pairs 4 and 6 were sub-telocentric (Fig. 1 and 4; Table 2). H. marginata had secondary constrictions in the centromeric region of the long arms of pair 10. In H. semiguttata (three populations) and Hyla sp. (aff. semiguttata), such constrictions occurred in the telomeric region of the short arm of pair 1 in some metaphases (Fig. 1 and 4).

\section{C-banding pattern}

The same heterochromatin pattern was observed in $H$. marginata, H. semiguttata and Hyla sp. (aff. semiguttata) (Fig. 2 and 4) using the C-banding method. The centromeric regions of all chromosomes were labeled. A strong heterochromatic band was observed on the long arm of pair 10, as well as in the telomeric region of the long arm in pair 1.

Nucleolar oganizing region - (NOR)

The NOR in H. marginata was located on the long arm of pair 10, coincident with the secondary constriction and the heterochromatin block. In $H$. semiguttata and Hyla sp. (aff. semiguttata), the NOR occurred in the telomeric region on the short arm in pair 1 (Fig. 3 and 4).

\section{DISCUSSION}

The diploid chromosome number of $2 \mathrm{n}=24$ is common in the order Anura and occurs in species of

Table 1. Number of specimens, collection site in Brazil and Argentina and Museum catalogue number of the examined specimens. $R S=$ Rio Grande do Sul State; $S C=$ Santa Catarina State; PR=Paraná State; BR=Brazil.

\begin{tabular}{llll}
\hline Species & Number of specimens & Collection site & Museum acession numbers \\
\hline H. semiguttata & 12 males & Cambará do Sul, SC; BR & $3114-3122$ and 3126-3128 \\
& 7 males & São Francisco de Paula, RS, BR & $3139-3145$ \\
& 4 males & Piraquara, PR; BR & $3704-3707$ \\
Hyla sp. (aff. semiguttata) & 4 males & Misiones, Argentina & $4908,3446,4909$ and 4910 \\
H. marginata & 8 males & São Francisco de Paula, RS, BR & $3090-3094$ and 3819-3821 \\
\hline
\end{tabular}




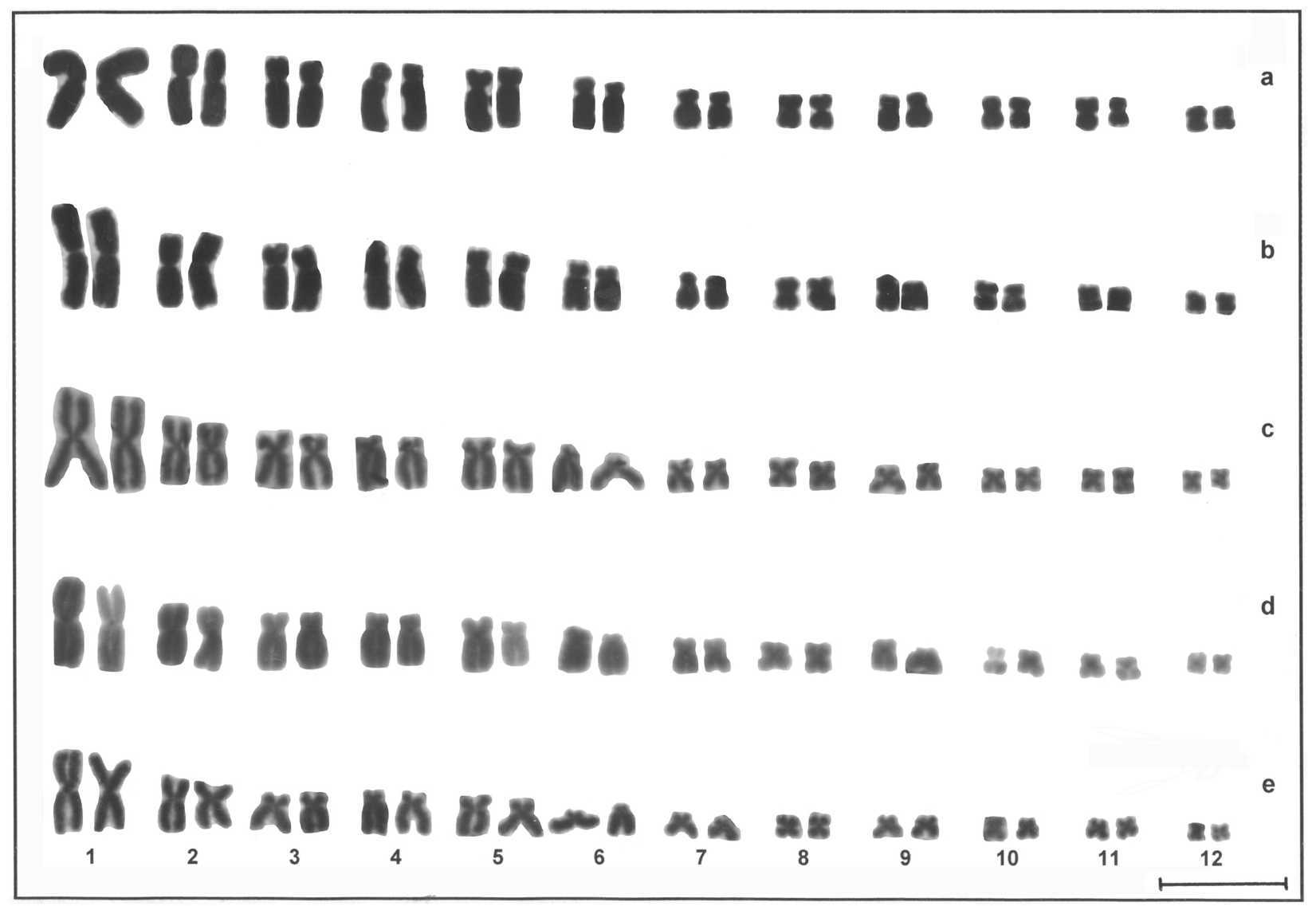

Fig. 1a-e. Karyotypes of H. marginata (a), H. semiguttata from São Francisco de Paula, RS. (b), Cambará do Sul, RS. (c) and Piracuara, PR. (d) and Hyla sp. (aff. semiguttata) (e) after Giemsa staining. Bar $=5 \mu \mathrm{m}$.

several families (Kuramoto 1990). Most species belonging to the genus Hyla show $2 \mathrm{n}=24$ or 2n $=30$ chromosomes (BEÇAK 1968; Rabello 1970; Bogart 1973; Kuramoto 1990; Anderson 1991; SKUK and LANGONE 1992; BALdissera et al. 1993; KAISER et al. 1996), which suggests a dichotomy within the genus Hyla, despite the fact that there are also other diploid numbers such as $2 \mathrm{n}=18,20,26,30$, 32 and 34 (Kuramoto 1990; Baldissera et al. 1993). According to Miura (1995), the appearance of Hyla species with $2 \mathrm{n}=24$ chromosomes can be related to a common ancestor with $2 \mathrm{n}=26$, and BOGART (1973) suggested that species with morphologically similar karyotypes can be considered to share a common ancestor. One of the possible mechanism to explain the change from $2 n=26$ to $2 n=24$ chromosomes may be related to centric fusion (MORESCALCHI 1990). The Hyla species with $2 \mathrm{n}=18,20$ and 22 chromosomes probably had their origin in the karyotype with $2 \mathrm{n}=24$ chromosomes (BogarT 1973). For the 30-chromosomes Hyla, centric dissociation probable is responsible for the increase in number and pericentric inversion have shifted the position of the centromeres in many cases (BogART 1973; KING
1990). As stated by Bogart (1973) the 30-chromosomes Hyla and the 24-chromosome Hyla were probably independently derived from a 26 -chromosome ancestor.

Despite the differences in external morphology among $H$. semiguttata populations, $H$. marginata and Hyla sp. (aff. semiguttata), these species show a very conserved chromosomal morphology. The karyotypes of $H$. marginata, $H$. semiguttata and Hyla sp. (aff. semiguttata) were very similar to other species of the pulchella group (H. p. pulchella, H. caingua, $H$. prasina, H. p. joaquini) (BALDISSERA et al. 1993; ANANIAS 1996) and to H. guentheri and H. bischoffi (RABER 2000), as well as to some neotropical and holoartic Hyla species (BogART 1973; ANDERSON 1991).

Comparison of the constitutive heterochromatin pattern of the three species studied with those previously described for the pulchella group and related species revealed that there were some common C-bands in most of them. H. prasina (BALDISSERA et al. 1993; AnANias 1996), H. p. joaquini (ANANias 1996), H. guentheri and $H$. bischoffi (RABER 2000) had the same telomeric band in pair 1 also found in 


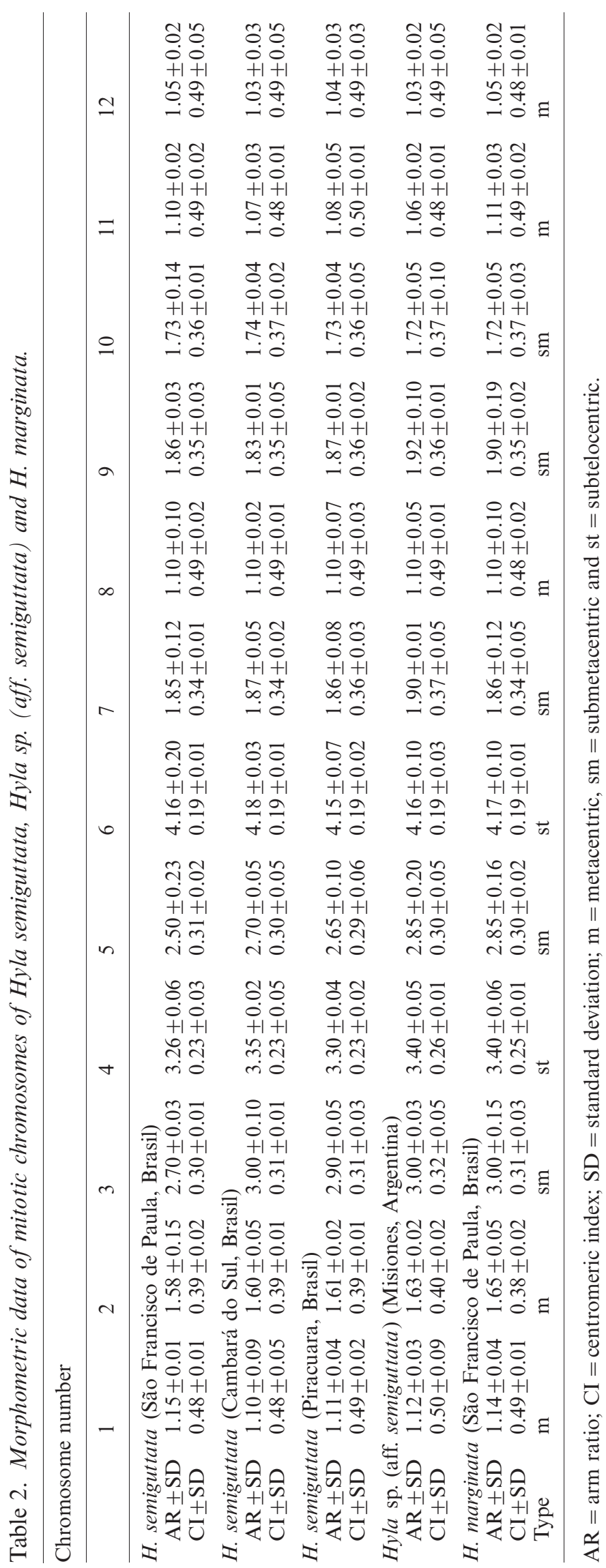




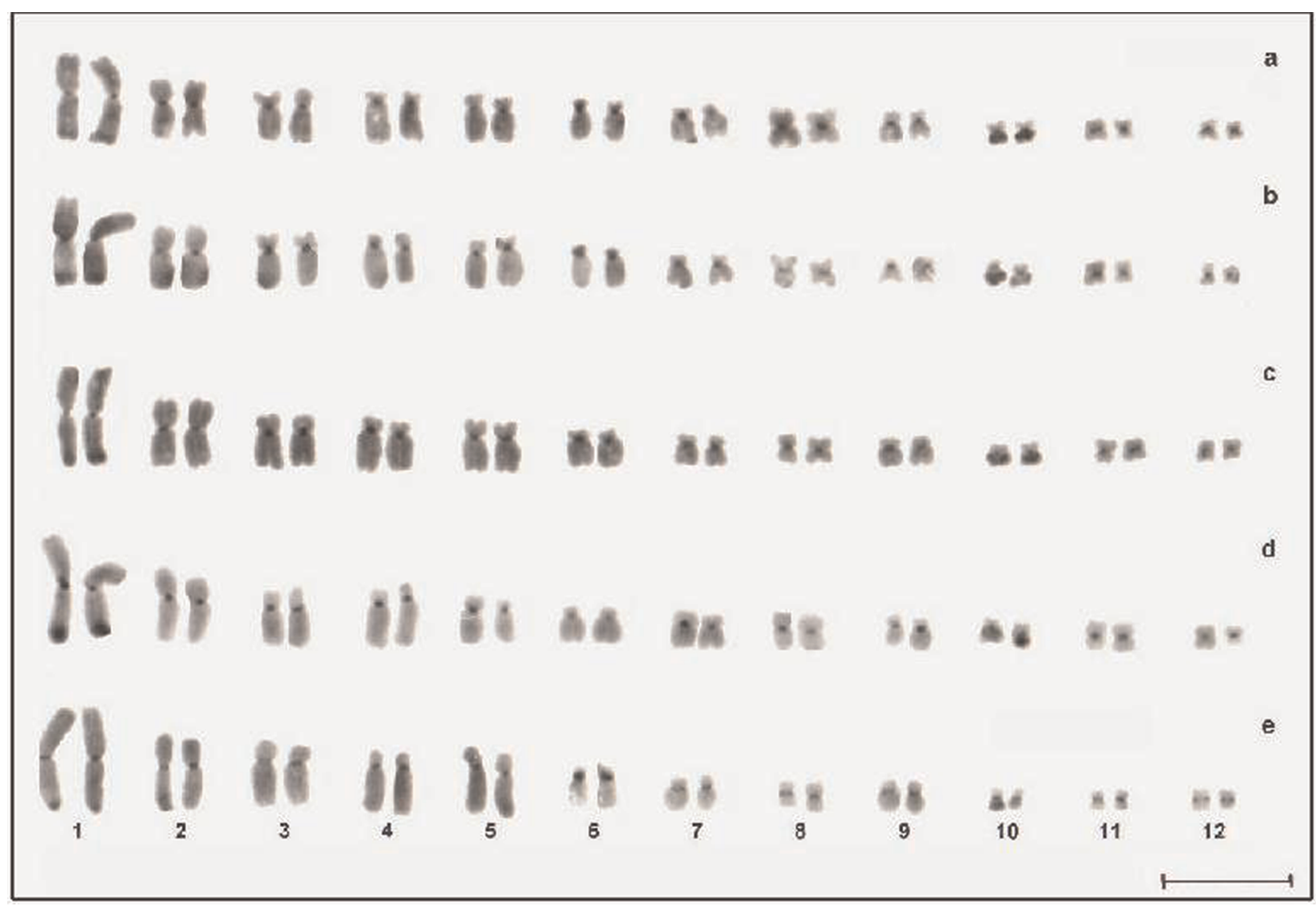

Fig. 2a-e. C-banded karyotypes of H. marginata (a), H. semiguttata from São Francisco de Paula, RS. (b), Cambará do Sul, RS. (c) and Piracuara, PR. (d) and Hyla sp. (aff. semiguttata) (e). Bar $=5 \mu \mathrm{m}$.

H. marginata, $H$. semiguttata and Hyla sp. (aff. semiguttata). However, this band is absent in $H$. caingua and H. p. pulchella (ANANiAs 1996).

Although $H$. marginata, $H$. semiguttata and Hyla sp. (aff. semiguttata) are morphologically different, their constitutive heterochromatin patterns were the same, confirming that they are very closely related. In addition, H. p. joaquini (São Joaquim - type location) (ANANias 1996) had the same heterochromatin pattern observed in $H$. marginata, $H$. semiguttata and Hyla sp. (aff. semiguttata), suggesting that they are more closely related to each other than to other species of the group. KASAHARA et al. (1996) reported similar results in three species of Bufo which had striking morphological differences but indistinguishable $\mathrm{C}$-band pattern, typical of species of the marinus group, but different from species in other groups (SChMid 1978, 1980, 1982; Matsui et al. 1985; SCHMID and AlMEIDA 1988; SCHMID and GutTenbach 1988; Herrero et al. 1993). H. marginata differed from $H$. semiguttata and Hyla sp. (aff. semiguttata) in the localization of the NOR. The

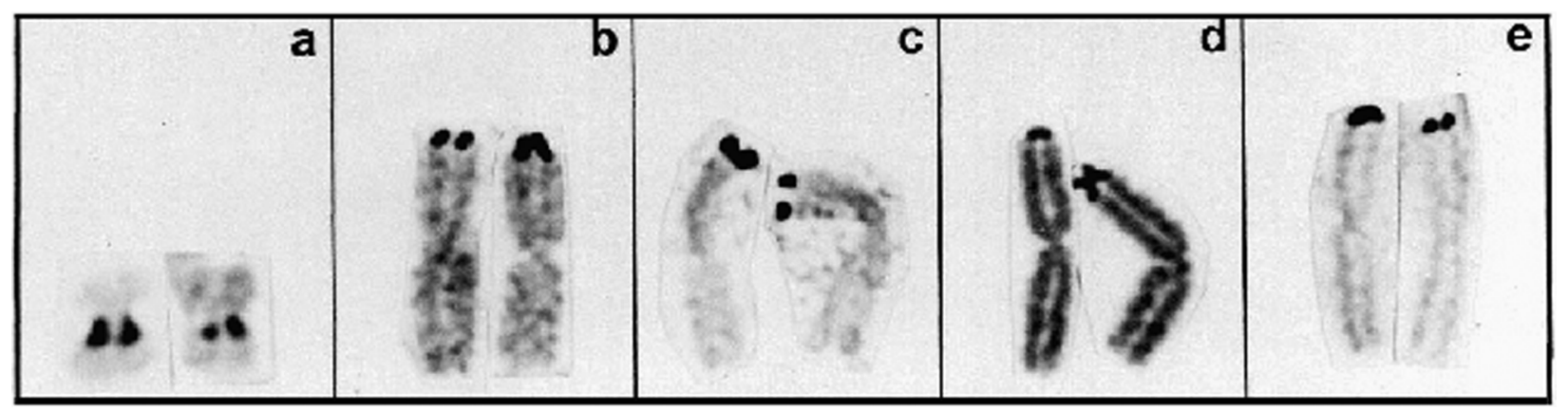

Fig. 3a-e. Silver-stained NOR of H. marginata (a), H. semiguttata from São Francisco de Paula, RS. (b), Cambará do Sul, RS. (c) and Piracuara, PR. (d) and Hyla sp. (aff. semiguttata) (e). 

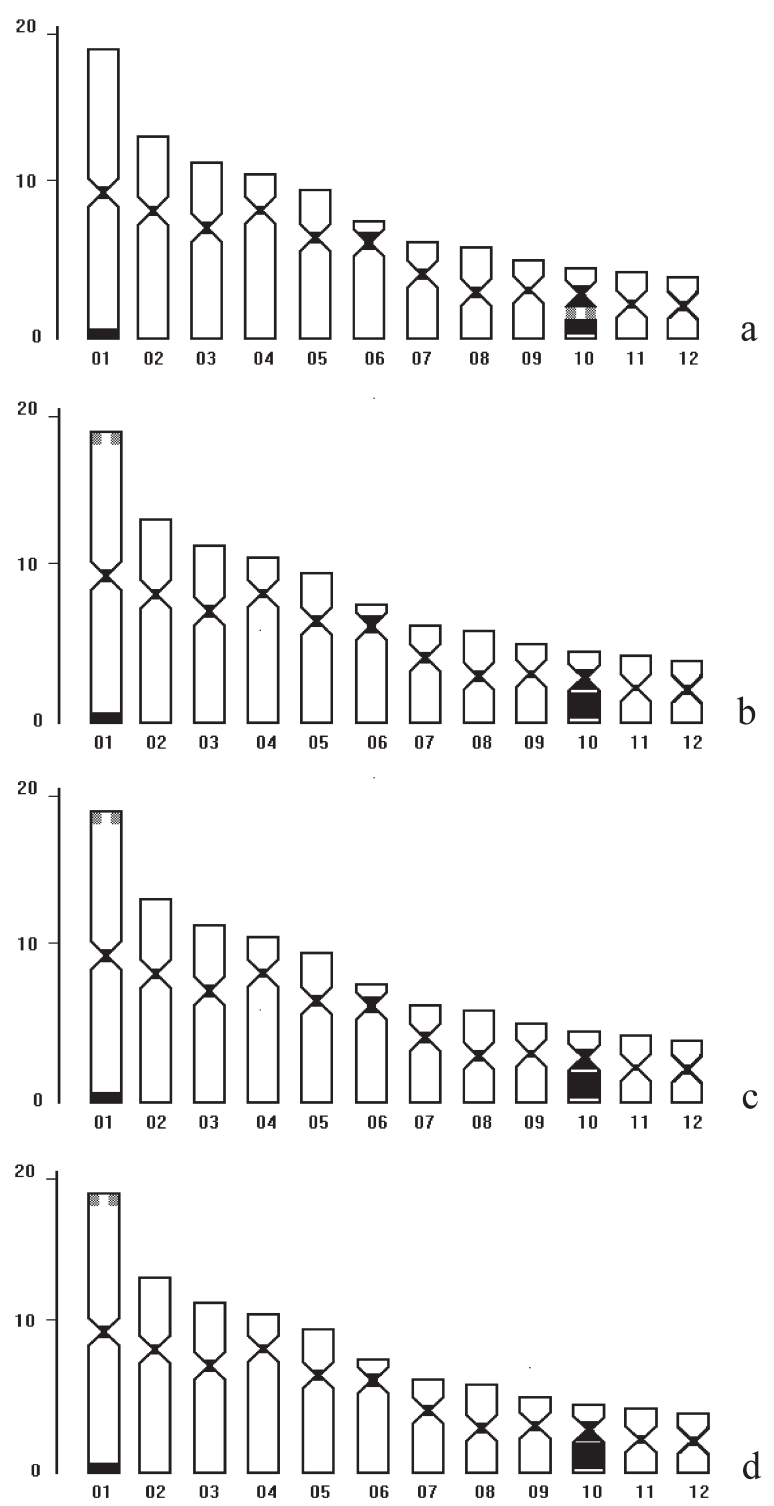

Fig. 4a-d. Idiograms of $H$. marginata (a), $H$. semiguttata (b) and Hyla sp. (aff. semiguttata) (c) (analyzed in the present work) and $H$. p. joaquini (d) (Ananias et al., unpubl.). Solid blocks denote heterochromatin, opened areas represent the secondary constriction and shaded circles denote NORs.

Ag-NOR staining in the telomere of pair 1 in $H$. semiguttata and Hyla sp. (aff. semiguttata) and in the near of pericentromeric area of pair 10 in $\mathrm{H}$. marginata may have arisen through translocations. H. p. joaquini also had an NOR in the telomeric region of pair 1 , suggesting a similarity to $H$. semiguttata and Hyla sp. (aff. semiguttata).

According to GARCIA and HADDAD (1999), there are differences in the advertisement call among the three populations of $\mathrm{H}$. semiguttata. However, cytogenetic analysis of these populations provides no evidence to support the hypothesis of their belonging to different taxa. On the other hand, the synonymization of $H$. semiguttata and $H$. p. joaquini to $H$. marginata, as suggested by LANGONE (1997), was not confirmed since only $H$. semiguttata and $H$. $p$. joaquini can be mistaken cytogenetically.

In conclusion, the biological differences within the Hyla species and populations of $H$. semiguttata studied here were not reflected in the chromosomal structure of these species, even though GolDMAN and BARTON (1992) suggested that genetic changes should be seen in the populational structure and should influence speciation and diversification. However, this lack of chromosomal variation does not mean that there is currently no speciation in progress. Our results also show that the relationship among $H$. marginata, $H$. p. joaquini and $H$. semiguttata and their populations may be better understood through molecular DNA analysis.

Acknowledgements - The authors thank Dr. Célio F. B. Haddad for his help in collecting some specimens and Klélia Aparecida de Carvalho for her technical expertise. P.C.A.G. was supported by a scholarship from FAPESP (process No. 98/06087-9).

\section{REFERENCES}

Ananias, F. 1996. Caracterização cromossômica de espécies e subespécies de Hyla do grupo pulchella (Amphibia, Anura, Hylidae). Master thesis. - State Univ. of Campinas (UNICAMP), SP, Brazil.

Anderson, K. 1991. Chromosome evolution in Holarctic Hyla treefrogs. - In: Green, M. G. and Sessions, S. K (eds), Amphibian cytogenetics and evolution. Academic Press, p. 299-331.

Baldissera Jr, F. A., Oliveira, P. S. L. and Kasahara, S. 1993. Cytogenetics of four Brazilian Hyla species (AmphibiaAnura) and description of a case with a supernumerary chromosome. - Rev. Bras. Genet. 16: 335-345.

Beçak, M. L. 1968. Chromosomal analysis of eighteen species of Anura. - Caryologia 21: 191-208.

Bogart, J. P. 1973. Evolution of anuran karyotypes. - In: Vial, J. L. (ed.), Evolutionary biology of anurans. Univ. Missouri Press, p. 337-349.

Braun, P. C. and Braun, C. A. S. 1980. Lista prévia dos anfíbios do Rio Grande do Sul, Brasil. - Iheringia, Ser. Zool., Porto Alegre 56: 121-146.

Caramaschi, U. and Cruz, C. A. G. 2000. Duas espécies novas de Hyla Laurenti, 1768 do Estado de Goiás, Brasil (Amphibia, Anura, Hylidae). - Bol. Mus. Nac. Zool. 422: $1-12$.

Cei, J. M. and Roig, V. G. 1961. Batracios recolectados por la espedición biologica Erspamer en Corrientes y selva oriental de Misiones. - Notas Biol. Facult. Ciencias Exactas, Fisicas y Naturales, Corrientes Zool. 1: 10.

Duellman, W. E., De La Riva, I. and Wild, E. R. 1997. Frogs of the Hyla armata and Hyla pulchella groups in the Andes of South America, with definitions and analyses of phylogenetic relationships of Andean groups of Hyla. - Sci. Papers Nat. Hist. Mus. Univ. Kansas 3: 1-41. 
Faivovich, J. 1996. La larva de Hyla semiguttata A. Lutz, 1925 (Anura, Hylidae). - Cuadernos de Herpetol. 9: 6167.

Garcia, P. C. A. and Haddad, C. F. B. 1999. Análise das vocalizações de anúncio (advertisement call) das espécies de Hyla relacionadas ao complexo de Hyla marginatal semiguttata (Amphibia, Anura, Hylidae). - Res. V, Cong. Lat. Am. Herpetol. 64.

Garcia, P. C. A., Vinciprova, G. and Haddad, C. F. B. 2001. Vocalização, girino, distribuição geográfica e novos comentários sobre Hyla marginata Boulenger, 1887 (Anura, Hylidae, Hylinae). - Bol. Mus. Nac. Zool. 460: $1-19$.

Goldman, N. and Barton, N. H. 1992. Genetics and geography. - Nature 357: 440-441.

Green, D. M. and Session, S. K. 1991. Nomenclature for chromosomes. - In: Green, D. M. and Sessions, S. K. (eds), Amphibian cytogenetics and evolution. Academic Press, p. 431-432.

Herrero, P., López-Jurado, L. F., Arano, B. et al. 1993. Karyotype analysis and nuclear DNA content of Bufo brongersmai Hoogmoed. - J. Herpetol. 27: 463-465.

Howell, W. M. and Black, D. A. 1980. Controlled silverstaining of nucleolus organizer regions with a protective colloidal developer:1-step method. - Experientia 36: 1014-1015.

Kaiser, H., Mais, C., Bolaños, F. et al. 1996. Chromosomal investigation of three Costa Rica frogs from the 30chromosome radiation of Hyla with the description of a unique geographic variation in nucleolus organizer regions. - Genetica 98: 95-102.

Kasahara, S., Silva, A. P. Z. and Haddad, C. F. B. 1996. Chromosome banding in three species of Brazilian toads (Amphibia-Bufonidae). - Braz. J. Genet. 19: 237-242.

King, M. 1990. Amphibian. - In: John, B. (ed.), Animal cytogenetics. Gebrüder Borntraeger, Berlin/Stuttgart, p. $1-241$.

Kuramoto, M. 1990. A list of chromosome numbers of anuran amphibians. - Bull. Fukuoka Univ. Ed. 39: 83127.

Langone, J. A. 1993. Caráterización, sinonimia y distribución geográfica de H. marginata Boulenger 1887 (Amphibia, Anura, Hylidae). - Res. III Cong. Lat. Herpetol. 228.

Langone, J. A. 1997. Caráterizaçión de Hyla guentheri Boulenger, 1886 (Amphibia, Anura, Hylidae). - Cuad. Herpetol. 11: 13-20.
Lutz, A. 1925. Batraciens du Brésil. II. - Compt. Ren. Soc. Biol. Paris. 93 (22): 211-214.

Lutz, B. 1973. Brasilian species of Hyla . - Texas Univ. Press, p. $74-85$.

Matsui, M., Seto, T., Kohsaka, Y. et al. 1985. Bearing of chromosome C-banding patterns on the classification of Eurasian toads of the Bufo bufo complex. - AmphibiaReptilia 6: 23-33.

Miura, I. 1995. The late replication banding patterns of chromosomes are highly conserved in the genera Rana, Hyla and Bufo (Amphibia: Anura). - Chromosoma 103: $567-574$.

Morescalchi, A. 1990. Cytogenetics and the problem of lissamphibian relationships. - In: Olmo, E. (ed.), Cytogenetics of amphibians and reptiles. Birkhäuser Verlag, p. $1-19$.

Rabello, M. N. 1970. Chromosomal studies in brazilian anurans. - Caryologia 23: 45-59.

Raber, S. C. 2000. Caracterização cromossômica de Hyla bischoffi e Hyla guentheri (Anura, Hylidae). Master thesis. State Univ. of Campinas (UNICAMP), Campinas, SP, Brazil.

Schmid, M. 1978. Chromosome banding in Amphibia I. Constitutive heterochromatin and nucleolus organizers regions in Bufo and Hyla. - Chromosoma 66: 361-388.

Schmid, M. 1980. Chromosome banding in Amphibia. IV. Differentiation of GC and AT-rich chromosome regions in Anura. - Chromosoma 77: 83-103.

Schmid, M. 1982. Chromosome banding in Amphibia VII. Analysis of the structure and variability of NORs in Anura. - Chromosoma 87: 327-344.

Schmid, M. and Almeida, C. G. 1988. Chromosome banding in Amphibia. XII. Restriction endonucleases banding. - Chromosoma 96: 283-290.

Schmid, M. and Guttenbach, M. 1988. Evolutionary diversity of reverse $(\mathrm{R})$ fluorescent chromosome bands in vertebrates. - Chromosoma 97: 101-114.

Schmid, M., Olert, J. and Klett, C. 1979. Chromosome banding in Amphibia III. Sex chromosomes in Triturus. - Chromosoma 71: 29-55.

Skuk, G. and Langone, J. A. 1992. Los cromosomas de cuatro especies del género Hyla (Anura: Hylidae) con número diploide de $2 \mathrm{n}=30$. - Acta Zool. Lilloana 41: $165-171$.

Sumner, A. T. 1972. A simple technique for demonstrating centromeric heterochromatin. - Exp. Cell Res. 75: 304306. 